A[-Ulum

Volume 15 Number 2 December 2015

Page 479 - 496

\title{
Toward Peace-Loving Attitude Trough Education Character
}

\author{
Dalmeri \& Antonius Atosokhi Gea \\ Indraprasta PGRI University and Binus University Jakarta \\ dalmeri300@gmail.com
}

\begin{abstract}
Efforts to solve violence had been faced by multi treatments. Violence in education is action over the standar of ethic and rule in education, either physically or disturbing the rights of ones. The actors can be anyone, including the chief of school, teacher, staff, student, parents and even society. Violence in education is assumed as effect of certain condition. Externally or internally, and it might happen with any trigger. This paper aims to analyse the importance of character building through peace-loving attitude to revitalize the actors of education as evaluation of structure and culture in the educational world. Our educational world recently sometimes shows its arrogancy and even militaristic behavior. While the basic tenet of education is to appreciate the understanding of human behavior in order to be enlighted and free.
\end{abstract}

Upaya untuk menyelesaikan kekerasan pun menemui tantangan yang semakin kompleks. Kekerasan dalam pendidikan merupakan perilaku melampaui batas kode etik dan aturan dalam pendidikan, baik dalam bentuk fisik maupun pelecehan atas hak seseorang. Pelakunya bisa siapa saja: pimpinan sekolah, guru, staf, murid, orang tua atau wali murid, bahkan masyarakat. Kekerasan dalam pendidikan diasumsikan terjadi sebagai akibat kondisi tertentu yang melatar-belakanginya, baik faktor internal dan eksternal, dan tidak timbul secara begitu saja, melainkan dipicu oleh suatu kejadian. Tulisan ini menganalisa topik yang sangat penting untuk digali kembali oleh para insan pemerhati pendidikan sebagai wadah refleksi dan evaluasi kinerja struktural-kultural terhadap praksis dunia pendidikan. Dunia pendidikan yang akhir-akhir ini cenderung bernuansa arogansi intelektual atau bahkan bergaya militeristik yang tidak mengindahkan norma-norma etis. Padahal pendidikan seyogyanya memanusiakan manusia menuju taraf pemahaman yang lebih mencerahkan dan memerdekakan.

Keywords:character education, love of peace; harmony; moral value;multicultural 


\section{A. Introduction}

The existence of violence and brutality phenomenon in humanistic history is sometimes opened or closed to public. One of the biggest agenda starting from this decade is a study about violence and its involved moral issues. Urgency and Importance of some studies about violence and brutality may lead to people consideration that violence and brutality cannot be parted from life context. As what Sigmund Freud said in his thesis that people have tendency to do bad thing (thanatos), and realize well that some violence done by them may result to a more dangerous one in the future.

Recently some people may think that people doing violence have psychology nuisance. This person has disability to socialize, solve conflicts, and he tends to become depressive-repressive for any matters so that he has mental disruption that makes him frustrated. He is mentally sick and hurtful. He keeps angry for unfairness that he thinks people do to him. Next, he becomes negative for some unfairness that happens surround him where he cannot do anything towards it.

Violence is real in Indonesian domain where multi-cultural and multi-ethnics lies. Any friction or conflict is possible to end up with murderer or massive brawl. Gang fight explodes amongst people either in country or city. The worse is when religious leaders possibly take part in it, than ethnic or religious conflict may happen as well.

There are four main factors boosting up why society does violence. The one, there is transformation happening in society. Modernization and globalization have been the enormous matters which let people feel continued anxiety. A process of culture transformation from traditional one to post-traditional will effectively create disorientation, dislocation and malfunction where these matters are categorized as economic, psychology and politic menace. Ways to manage traditional conflict in facing pluralism in society is no longer done effectively. Slowly but surely, a tendency of premordialism happening into society and aggression happening out of the society will get worse when the society is far from modernism as positive process towards wealthy and fairness.

The two is accumulation of hostility among the society. There are undeniable exclusive tendencies amongst either religion's or ethnic practitioners who effectively provoke what ensues in a society. To make someone convert to other religion, to influence kids to make a distance with friends who have different religion, to rumor some hocus pocus of 
other religious group, to flow provocation amongst religious groups are some examples of the undeniable tendencies. ${ }^{1}$

The three is hardship in society. People cannot be far from violence in which daily conflicts are difficult to solve, instead the violence itself will directly boost up different problems where irresponsible ones can take them for situational benefit. As result, the red line for Indonesian plurality which consists of thousands of ethnic group having different religions, spreading in islands and living in high mobility has begun to distract.

The distraction existence is proved by society that tends to dwell in atrophy of being more solid than primordial environment. This is a sequence of narrow-minded attention towards a definite society. Ability to feel the sense of "we are in one union" or "we are in one region" has been undermined by the self-perspective of "they" and "we", where "we" has narrower meaning of the real context "we", and "they" as the other persons who are defined as threads. Ideally, this kind of union can be united only when it has adequate psychological ability to tolerate others. This goes to a goal for acceptance without a tension of tradition variety trustfulness, life style, social matter, point of view and religious habits.

The four is liberal democracy as an institutional system of violence. All social conflicts and compulsory are solved irrationally, subjectively, personally, unfairly and arrogantly done by cogitation, intimidation, thread and oppression. Some brutality done by some affiliated people towards some social organization as their way to uphold their status quo anywhere they act. At the same time, they also sermon the society about value of "Pancasila", nationality, unity and coalescence, etc. The purpose is only to put people in sarcasm and harassment.

In this Guided Democracy, as a reaction of to form people ideology, the new order government has been in a move to find new policy of depoliticisation. Political parties are neutered. Political action, even holding a more-than-five-person meeting is prohibited. Meanwhile, the construction of this nation goes for a meaning that the destiny of Indonesian people will be the top person matter. Regional regulation, structure of local-traditional leadership which is also autonomous is ruined. At almost, head of village is possible to play role in exploiting his people.

${ }^{1}$ Rahmi Damis, "Nilai-Nilai Pendidikan Karakter pada Ajaran Cinta dalam Tasawuf." Al-Ulum 14, no. 1 (2014): p. 142. 
Attention of society is centered nowadays to primordial element. Any government policy must be accepted. People are only able to watch this nation restructuration done frontal and sporadically. The worse is that the restructuration that mostly give profit to other nations, which surely develop better than our nation, often makes people the victim of restructuration itself. Kedungombo phenomenon is one of the examples. People, willy-nilly, must hand over their lands, home and woods with improper compensation added by some extortion. When they did not want to do that, they will be judged as PKI or extremist. Tread and intimidation becomes trend on how to end up the conflict under new order authoritarian regime.

As a result, disappointment, anger, feeling of unfairness, hate and revenge are accumulated in to them. Those emotions are lumped up and released to others. The others can be government, bureaucrat, army, Tionghoa for sure, and others ethnic, immigrant, native, religious group, etc. the flow of individual and group violence, ethnic exploitation, fanatic, chauvinism, tribalism, even nativism is a result of the continued oppression.

\section{B. Reforming a Peaceful Education Culture Throughout Character Building}

The exact opposite of historical setting the roots of violence, needed awareness of multiculturalism signals willingness to accept the other groups as a whole, without neglecting the cultural differences, ethnic, gender, language, or religion. ${ }^{2}$ Complexity and variety aspects of life as a unique, ethnical, religious personal entity, that is different one to another, have signed that collaboration amongst each element of people becomes an urgency. On the other hand, multiculturalism identifies a need of understanding towards some cultural values in the society itself. ${ }^{3}$

Dealing with character building, multicultural awarness that is built into the students will help them to understand, accept and appreciate others from different ethnic, culture, value and religion. This multicultural awarness is applied towards the students by neither hiding Mei 2003.

${ }^{2}$ Mun'im A. Sirry, “Agama, Demokrasi, dan Multikulturalisme”, Kompas, 1

${ }^{3}$ Ali Maksum and Luluk Yunan Ruhendi, Paradigma Pendidikan Universal di Era Modern dan Postmodern: Mencari "Visi Baru” atas "Realitas Baru” Pendidikan Kita, (Yogyakarta: IRCiSoD, 2004), p. 244. 
other culture nor uniting multi-culture into one mutual culture which the two are possible to make cultures from some regions tend to vanish gradualy but surely. Through multicultural education acknowledged, each culture has its own truth value that requires understanding relativism cultural values. ${ }^{4}$

Is it a fact that nobody wants to do violence. However, the other fact shows the contrary one that violence keep happening. Even, the number is increasing. Ironically, violence does not only happen in war and massive brawl, instead it also happens in educational range whereas a place to inseminate moral value, civilization and knowledge. Clark Kerr, the previous dean of California University, stated that school or education is a blue print of the future society. What is wrong with our education? Is that true that the suspicion of Roem Topatimasang, a popular education practitioner, that is stated in his book Sekolah Itu Candu: the real school or education is already deceased when it has been far from its real function?

When we investigate orderly in a line with the concept of our education system, our nation is loaded with refraction which leads itself to a process of dehumanization either from its material substance or from teaching methodology. Teaching material in primary school to university level still directs to link and match concept. This concept should have got its diversity and flexibility in order to connect and handle life problems.

When we watch closely into Indonesian national education that now often goes to a meaning of 'school for future work', we may find out a big number of subjects leading to, mostly, cognitive ability. School nowadays prepares a tendency of people being materialistic. The effect of materialistic domination make ethics and moral subjects at school, such as religion or social, gradually loose..$^{5}$ The worse, some subjects related to affection function are imitatively changed to the allocation of cognitive skill, too. Students lear religion only to pursue the requirement of completion. ${ }^{6}$ This is a materialistic and ironic modus. Is that totally true if materialism is the root of any violence in the world?

\footnotetext{
${ }^{4}$ Paul Suparno, "Pendidikan Multikultural”, Kompas, 7 Januari 2003.

${ }^{5}$ Rahmawati Caco, "Islam Concept about Tolerance and Religious Freedom." Al-Ulum 14, no. 2 (2014): p. 394.

${ }^{6}$ Abdul Munir Mulkhan, "Dunia Pendidikan sebagai Perang Kekerasan", in Franz Magnis Suseno (ed.), Melawan Kekerasan Tanpa Kekerasan, (Yogyakarta: Pustaka Pelajar, 2000), p. 168-169.
} 
Pedagogic approach or one direction approach that places teacher as a role model and puts students as like an empty bottle has been general methodic point of view. Anything revealed by the teacher becomes a single truth. On this stage, indoctrination, ideology and homogeneity, in their own proper dosage, can build fake thought about what has lasted and what is going on.

Putting student as object in education is not completely wise. This is in a line with what Paulo Freire, one of education personages, believes that an end goal of education process is to humanize human or forming a humanity into the human. He stated that the importance of this is to realize that we do not need to live only, but we also need to exist. By our existence, we can exist either in our world or in 'other world'. In same position, Freire surely stated that human is basically a being who has independence, so that human beings in fact capable of transcendence with all the reality that revolving around. ${ }^{7}$

For similar purpose, Ki Hajar Dewantara had an actual idea that was not only smart at that time but also applicable until now. He strongly appointed education practice that put students in their natural behavior instead of doing order. This was purposed to trigger a better developmental life and mental. This way of educating is named 'among'. The basic thought of this approach is: (a) independency as a requirement to life and move towards mental and spiritual betterment; and (b) natural call as a requirement to life and to attain a betterment vastly.

The genuine of formal education can be a transferring media of knowledge and civilization. By pedagogic practice, learners are set to understand how to transfer culture experiences into their future life. However, paradoxically, the real context of knowledge and culture, systematically and institutionally, has been being dilemmatic because it is claimed as either politicians or education bureaucrats.

The education decadence appears from a fact happening in new order. Educational institution just like school has been a part of governmental bureaucracy in defending its power and importance. How new order monopolize the meaning of history by showing film of $\mathrm{G} 30$ $\mathrm{S} / \mathrm{PKI}$ that is obliged to be watched by learner each year on every the

${ }^{7}$ A. Malik Fadjar, "Pendidikan sebagai Praksis Humanisasi Aspek Kemanusiaan sebagai Basis Pembaharuan Paradigma Pendidikan Nasional”, in Said Tuhuleley (ed.), Reformasi Pendidikan Muhammadiyah: Suatu Keniscayaan, (Yogyakarta: Pustaka Suara Muhammadiyah, 2003), p. 58-59. 
thirtieth of September is one example of the bureaucracy. What happens has been indicated that when knowledge is on progress in teaching learning process, there will always be intervention and politic bias in snatching up the meaning of education itself.

In the past decades, the practice of national education is no longer done on a basic of thorough holistic meaning of human and humanity. Therefore, some reformation in education has been directed to prepare a new society becoming more ideal. This society goes for a meaning of a group of people who understand right and compulsory, and they play role to develop this country. Esence and goal of national education is a process to form cultural politicsin certain prespective which goes for a better future. Through pedagogical activities, overview of ideal society was outlined in the minds of students so that a process of enculturation and acculturation. This thought describes a meaning of educational institution as learning media attempt social function and politic. ${ }^{8}$

The education system in Indonesia is still partial. There are many viewers think that the education in this nation is in error management either in its basic concept or in teaching method. Basic concept of education is to form Indonesian people wholly that is done in character building formation. As the final result of the basic concept, it is expected that people can gain self-existence, instinct, moral, ethics and good character (akhlaqul karimah). This is in a line with what Allah Exalted and Majestic is He wants.

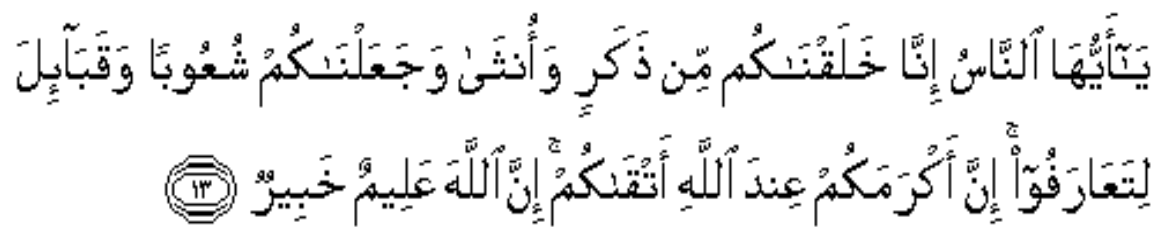

Alhujarat 49 verse 13: O mankind! We created you from a single (pair) of a male and a female, and made you into nations and tribes, that ye may know each other (not that ye may despise (each other). Verily the most honoured of you in the sight of Allah is (he who is) the most righteous of you. And Allah has full knowledge and is well acquainted (with all things)

Related to this verse, the meaning of education goes to four main pillars of education as what has been stated in an orientation noted by UNESCO, that is (1) learning to know, (2) learning to do, (3) learning to

${ }^{8}$ Surochman, “Renungan untuk Dunia Pendidikan”, Republika, 11 April 2007. 
be, and (4) learning to live together in order to form good character and good behavior. Prophet Muhammad Peace and Blessings be Upon Him also stated that:

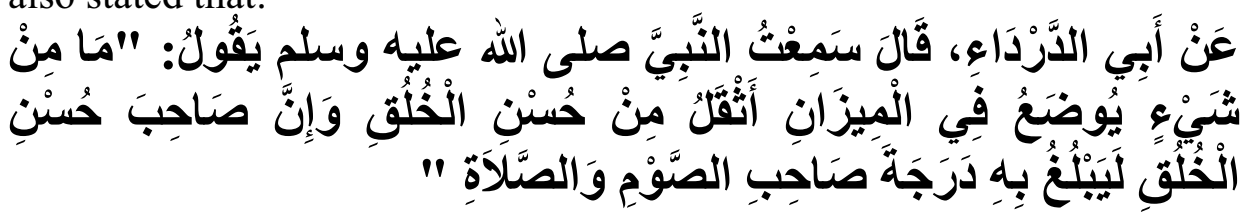

Abu Ad-Dardh narrated that the Messenger of Allah said: "Nothing is placed on the Scale that is heavier than good character. Indeed the person with good character will have attained the rank of the person of fasting and prayer." (Imam Abu Daud).

Teaching concept done nowadays emphasizes aspect skill, life skill and maths. At this time, educational process always stress on the cognitive ability, and less attentive in affective skill building. Education management in the past years ago that stressed on cognitive and abandoned other dimension, truly has created persons in split personality. As an example, how religious life physically gets better and better for any society level. However, on the other hand, there are also a big number of misguided people. Corruption, collusion and nepotism happening nowadays are examples of the existence of these people. The worse, some of them come from educational environment.

This is not in a line with what Benyamin Blom stated that school or institution is basically in a function to process humanistic area. This is called Education Taxonomy which forms affective domain, develops cognitive domain and drill psycho-motoric skill or conative domain. ${ }^{9} \mathrm{We}$ also can say that young generation as one who continues what has been stated as final goal of success life is a generation that has no religious statements into the life context. In general terminology, we can name what they have as intellectual quotient, emotional quotient and spiritual quotient. They are the goals of what any school must have.

It is a note that all parties must be reminded about education philosophy from Paulo Freire that is actually adopted to our education. It is "what she/he will be" instead of "what she/he is". This means all educators must have an ability to develop learner capacity in understanding life. Humanistic principle must not be done humanistically

${ }^{9}$ Muhammad Zaenuddin, Membangun Wacana Intelektual: Perspektif Keagamaan, Sosial-Kemasyarakatan dan Politik, (Yogyakarta: Pustaka Pelajar, 2004), p. 50. 
but authentically. Humanistic principle lying in education regulation is intended to build Indonesian people up to better moral and character. Therefore, to make it come through, education must be done critically and communicatively without any harassment.

\section{Evaluating Effect Between Violence Pattern and Respond in Society}

When we connect violence in education, there are many things can vary whether it is a war or massive conflict. However, based on the doer, victims, condition, trigger, motif or conflict resolution possibly done, there are many similarities in typology between the two. The best similarities amongst war, massive conflict or any violence in education might happen for a trigger which is precipitation stuck between doer and victim. The trigger must be some enormous matters, or even a very simple matter which they are sometimes so specific and casuistic.

Similar trigger may not affect the same to both doer and victim. This happens the almost the same to some cases. Violence occurrence may be getting into something bigger, crimes. When the doer and the trigger is not tranquilized, the next conflict may follow. No matter what, violence in education must be stopped. Preventive action or saddzu aldzari'ah basically are different one to conflict resolution in solving problem. When preventive action is a way to minimalize the condition, conflict resolution tends to end up what has happened before. The condition is antecedent variable that influences the trigger subconsciously, internally and externally. Internally, education in this nation is apprehensive. This can be judged by physical appearance of broken school, high number of dropped out students, low prosperity of the teacher to less facilities that most schools may suffer.

This internal condition is the most influent factor to learner behavior that mostly goes for violence. Merton stated that false education will influence both teacher and learner to freeman behavior. ${ }^{10}$ In a line with Merton, Johan also stated that our current education thus produce juvenile delinquency, criminality, social dependence and the disintegration of the nation. ${ }^{11}$ The worse condition is near with the

${ }^{10}$ Guno Tri Tjahjoko, "Pendidikan dan Premanisme", Jawa Pos, Rabu Pahing, 18 September 2002.

${ }^{11}$ Johan "Sistem Pendidikan Menyimpang Koridor", Jawa Pos, Senin Pahing, 19 Agustus 2002. 
external condition of education, in social or in culture, that in reality has transferred itself to the worse because of modernism. Narcotics, porn, free sex are parts of external condition.

Modernity has parted the continuum chain of reality to spiritual metaphysics. Education is not only grounded by real world paradigm that is often more secular and lower than any religious matter. On the other hand, education is not a set of mental reformer, character builder or skill booster. However, it is a media to facilitate the human to experience and determine history. In short, smartness is not only all about achievement but also spiritual and religious accomplishment.

On the other hand, intellectual attainment must be gained from a process of education in order to found our inner ability, selfidentification, sense of responsibility, egalitarianism, and normative sense connecting with moral and value. Education must help learner to shape sense and feeling. Education must also form learner to be more patient, more humble and more solider to others. In short, school must be patiently patient in sensing, feeling, willing the students. School must bring about cognitive, affective and conative reflection to the learners simultaneously.

Education is actually oriented to previse young generation in handling life construction. Therefore, education is needed to ennoble our life. On this stage, education is in a challenge for not only to help students to create a success life but also to make it purposeful. Therefore, basics in education are urgently needed as a part of preparing the learners to face the life. ${ }^{12}$ From some glitches in education mentioned before, the phenomenon can build up a frame of thought about the importance of non-violence/peace education. This can be gained if concept in education itself has been developed effectively in the basis of similarity principle, independence to express opinion and thought freely. Therefore, concept in education must content a clear goal, subjects, methods, learning model, policy and learning atmosphere of peacefulness.

The flow of globalization has brought about social to a range of cosmopolitan between country, culture, religion, language, race, ethnic, gender, social status and plurality. This means that education must be in a process of learning to live together. To support this statement, universal humanistic value, culture, moral and religion needs to be upheld, so that

${ }^{12}$ Mochtar Buchori, Pendidikan Antisipatoris, (Yogyakarta: Kanisius, 2011), p. 
education becomes more humanistic. Religion, islam, has fulfilled sorts of guidance in forming positive character (akhlak al-karimah) and in hampering down negative emotion (akhlak al-madzmumah).

Willingness to attempt peaceful education can be done by understanding the cause of violence itself by determining more social intrigue and by inspecting atmosphere heat that may cause brutality. Camarra explains that the spiral of violence is begun from institutional violence that means violence that is possibly attempted subconsciously in a regulation of an institution or system. This can support people doing bad things, such as: humiliation, unfairness and hopeless condition. When someone is in this situation, he is not far from being a slave.

After the violence 1 is succeeded form in, violence 2 will be following. This is a continuity of counterpart session that appears like harrashment, revolution, terorism or crimes. The $3^{\text {rd }}$ violence mostly appears as pressure or repression that comes up as a respond to the $2^{\text {nd }}$ violence. This often demands for police interferency and a lot of military support.

The form of violence keeps in its track. A solution for a problem may creat another unexpected problem. Just like a mutan, violence floated onto a society is because of reaction towards some unaccepted condition. This connection is like a never ending story of violence. To avoid and to minimalize this kind of violence to happen in schools, each case occurred must be analyze for a better solving stages done by authorized people.

Postponed solution or temporary solution often triggers continuous harrashment. Indeed, it is not easy to declare a form or a pattern of acceptable solution because, basically, solution of problems has character of specification, or even, because improper solution, a conflict is possible to be an incident. All those problems are only needed to be clarified clearly in government regulation that must be done consistantly.

Related with some issues in education in the last few years, the existence of violence in educational institution like what happened in IPDN ( an institution to educate future leader)gives signal of the presence anarchism, in the other word: brutalism brings about educational symbolic. The conflicts were so shoddy until Way-Kambas as a training field for elephant was scored better than IPDN. When Way-Kambas trains animals, IPDN trains human; but still, animal is much better than human. This kind of problem that tickled DKI Jakarta governor, Basuki Cahaya Purnama with nickname Ahok, to purpose the cut off the 
institution lisence. The statement of Ahok created controversion amongst societies and boosted up protests from different level of society especially the heads of different regions.

What happened in IPDN statesclearly to us that educating people is not only about giving stimulus respond in classical conditioning, reward for success learners, punishment for the failed ones. This has been implemented by behaviourist like Ivan Pavlov and BF Skinner who agrees that human has thought, feeling, creativity, outstanding talent. Behaviorism system in education interpreted falsely makes this theory not able to accommodate the real potentcy of the human themselves, but instict. ${ }^{13}$

The concept of stimulus respond is often applied without concious concern. Technic used is the same like in animal training. Anxiety, feeling, humanism is very undeveloped. Therefore, when the theory is going to be applied to educate human, it tends to use aspect of basic skill only. Theory of education for human is far developed as the development of human mentality, such as cognitifism, mentalism and constructivism. To make this far from crucial problems in future education, we need to reconstruct system of education platform that is more modern and humanistic. Some experts of psychology cognitive believes that learning process must become meanigful learning. Based on its logic concequency, mehcanism in educational process must be in a line with a goal to form point of view to a better behaviour, and it is able to be considered morelly and intellectually.

The idea about non-violence or piece education is founded by spirit of tolerancy and solidarity of universal humanistic. Next, this can be historical phenomenon and optimism to change and reduce Barbar culture into a horizoned order for a more progressive and more egaliter purpose. In this stage, an urgency topic is used to dig up the deep thought of education observer. It also becomes a scoop of reflection and final evaluation of structural-cultural performance towards the practice of Indonesian education that probably still disobeys the proper ethical norm of education. In the future, it is expected that better understanding of what is being learned may bring learner to concern more religious, culture and social value in the society.

${ }^{13}$ Pranowo, "IPDN Bukan Pusat Pelatihan Binatang", in Kedaulatan Rakyat, Rabu Pon, 11 April 2007. 
Violence in education is a behavior that trespasses ethic code and rules in education. Either in physical or mental abuse. The doer can be anyone: principal, teacher, staff, student or parents. ${ }^{14}$ Violence in education happened because of internal or external factors. This does not just happens, but there is a trigger. As a result, antecedent variable, independent variable, intervening variable and dependent variable are linking to a spiral chain. In short, violence can occur anytime done by anyone as long as there is a trigger.

Eric Hoffer claimed that the main factor to boost up violence to happen is a massive protest caused by hate, imitating friends, temptation from different side either friend or leader. ${ }^{15} \mathrm{Hocus}$ pocus of anxiety, curiosity of illegal move may create (gang, club,etc). They pretend to go against something. Meanwhile, a supporting element of massive movement can appear in many forms bad happening. Therefore, to avoid violence, peace education is the best solution.

Peace education creates good character building that triggers people to end up conflicts in creative way instead of stiff way. In this context, peace education depends upon its user satisfaction. The hard session is when the society cannot meet their satisfaction in accomplishing the conflicts. Indeed, creative way in solving problems looks plain, but it is much better in creating win-win solution rather than all things related with uneasiness. ${ }^{16}$

The success of peace education is not shown in numbers, but it goes more to a competency quality to respond the hardship in life done in togetherness. Peace education unites many pedagogic tradition and educational theory altogether. It also develops some initiative opinion to better the learner throughout learning process. Peace education is done in dynamic, inter-disciplinary and multicultural. Some education experts like John Dewey, Maria Montessori, Paulo Freire, Johan Galtung, Ellese, Kenneth Boulding, etc. had been doing this in the past time.

${ }^{14}$ A. Ridwan Halim, Tindak Pidana Pendidikan (Suatu Tinjauan FilosofisEdukatif), Jakarta: Ghalia, p. 105. Abd. Rahman Assegaf, Tindak Pidana Pendidikan dalam Asas-asas Hukum Pidana Indonesia (Suatu Tinjauan Yuridis Edukatif), (Jakarta: Ghalia, 1985), p. 28.29.

${ }^{15}$ Eric Hoffer, "The True Believer", in Masri Maris (terj.), Gerakan Massa, (Jakarta: Yayasan Obor Indonesia, 1988). P. 49.

${ }^{16}$ Djohar, Pendidikan Strategik: Alternatif untuk Pendidikan Masa Depan, (Yogyakarta: LESFI, 2002),p. 106. 
In the chapter about character building by peace education, peace is concerned not only as the nonexistence direct violence, but it also creates positive condition. Peace education, therefore, includes all peaceful aspects. Peace education is intended to enhance three aspects: knowledge as cognitive domain, skill as psycho-motoric domain and attitude as affective domain which globally develops peace culture.

A definition of material and methods in peace education lies like this: first, peace education builds knowledge that contents selfawareness, prejudice, other issues like conflicts, war, no-violence, environment, ecology, nuclear and other weapons, justice, power, resolution theory, avoidance and conflict analysis, culture, race, gender, religion, human right issue, attitude, responsible, globalization effect, labor-ship, poverty and international economy, international law and justice, UN, instrument, standard and international system, AIDS and drugs.

Second, skills comprehended in peace education cover communication, reflective activity, active listening, group work, empathy, obligation, critical thinking, problem solving ability, artistic and esthetic appreciation, ability to solve conflicts, negotiation, conflict resolution, patience, self-management, responsible, imagination, ideal leadership and vision concern.

Third, attitude matters in peace education content ecology apprehension, respect, tolerance, respecting differences, understanding culture, gender sensor, care and empathy, non-violence reconciliation, social responsibility, solidarity, insight for global resolution.

Peace education is contemplated to develop skills, attitude and learner ability by participatory and cooperative learning method in tolerated, care and respectful environment. By dialogue and exploration, teacher and students do some experiments for creative learning. The learners grow up in responsible manner atmosphere to concern more how to develop their own capacity, when teacher's job is supervising the peace situation in it.

Peace education is a chance to improve prosperity of learner, put peace at the very first place, build up self-responsible and socialresponsible towards either the educator or the learner. ${ }^{17}$ By some trainings and this social action, teachers of peace education concern that

${ }^{17}$ Nazar Husain HPW, "Interreligious Relation And Violence on Religion in Indonesia Religion Philosophy Perspective." Al-Ulum 14, no. 2 (2014): p. 318. 
there may best ways to keep away from violence. Even Magnus Haavelsrud, a Norwegian peace educator, stated that there is no single answer of how education can contribute the best for the world. Somehow, high intensity for people going for education can be the best way for mobilization of needed peace.

By central learning of skill boost, peace education becomes so relevant for any education either in the city or in the country. Its education management is good because it covers diversity of the users. It is durable to use formal or informal curriculum. Moreover, by social context, culture, economic, politic, teacher is free to form material and specific methods teacher may also adapt the peace education in formal subjects such as language, mathematics, science, history, language, social and art.

Peace education does not teach the learner how to think an sich, instead it teaches how to think critically. In this context, it is possible there is conflict towards participatory matters and holistic matters because it is designed traditionally in its main standard. Beyond everything, peace education does not have any intention to reproduce but to transform. Connecting with this, John Dewey stated that there are many people who realize that to educate future generation is not a big problem, instead it will make better humanistic future for people.

One way to handle the challenge in education is that what peace education does by bridging some matters for a goal of support. It is the same point like other education, peace education depend heavily to family and social support. When it happens, the final goal is demanded. Changing will be happened. Think globally, act locally has been the main point of better education by connecting theory and practice and by transferring international issue to personal behavior. A peace educator does not to work individually. This is because international people who move actively and grow throughout some links, nationally and internationally. Caring society, educators and activist in many ages are in a big intention to promote how to do peace through education.

\section{Conclusion}

Character building that suggest people to do all in peace, when in this stage is done by education has been to good intention. Besides by using good system and methods, it also has construction model hat is applicable to any level of education. The peace model is able to be applied in order to do the best teaching process. To make this work, class 
conduct, interaction in learning and lecturing in humanistic approach will be the best ways.

Between educators and learners, a multi-way communication is created in order to create democracy in the class. To do instructional model of peace education, some simple facilities are needed such as flexible classroom and conducive atmosphere. Finally, in peace and positive condition, it is expected that wealthy life, fairness, gender equality and human right will be happened in harmony

\section{REFERENCES}

Assegaf, Abd. Rahman. 1985. Tindak Pidana Pendidikan dalam Asasasas Hukum Pidana Indonesia (Suatu Tinjauan Yuridis Edukatif). Jakarta: Ghalia.

Assegaf, Abd. Rahman. 2004. Pendidikan Tanpa Kekerasan: Tipologi Kondisi, Kasus dan Konsep. Yogyakarta: Tiara Wacana.

Buchori, Mochtar. 2001. Pendidikan Antisipatoris. Yogyakarta: Kanisius.

Caco, Rahmawati. 2014. "Islam Concept About Tolerance And Religious Freedom." Al-Ulum Volume 14. Number. 2.

Damis, Rahmi. 2014. "Nilai-Nilai Pendidikan Karakter pada Ajaran Cinta dalam Tasawuf." Al-Ulum Volume 14. Number. 1.

Djohar, "Sistem Pendidikan Menyimpang Koridor", Jawa Pos, Senin Pahing, 19 Agustus 2002.

Djohar. 2002. Pendidikan Strategik: Alternatif untuk Pendidikan Masa Depan. Yogyakarta: LESFI.

Guno Tri Tjahjoko, "Pendidikan dan Premanisme", Jawa Pos, Rabu Pahing, 18 September 2002.

Halim, A. Ridwan. 1985. Tindak Pidana Pendidikan (Suatu Tinjauan Filosofis-Edukatif). Jakarta: Ghalia. 
Hoffer, Eric, “The True Believer”, dalam Masri Maris (terj.). 1988. Gerakan Massa. Jakarta: Yayasan Obor Indonesia.

HPW, Nazar Husain. 2014. "Interreligious Relation and Violence on Religion in Indonesia Religion Philosophy Perspective." Al-Ulum Volume 14, Number. 2.

Kemmis, S. \& McTaggart, R. 1988. The Action Research Planner. Victoria: Deakin University.

Madya, Suwarsih. 1994. Panduan Penelitian Tindakan. Yogyakarta: Lemlit IKIP Yogyakarta.

Maksum, Ali dan Luluk Yunan Ruhendi. 2004. Paradigma Pendidikan Universal di Era Modern dan Postmodern: Mencari "Visi Baru" atas "Realitas Baru” Pendidikan Kita. Yogyakarta: IRCiSoD.

Mun'im A. Sirry, “Agama, Demokrasi, dan Multikulturalisme”, Kompas, 1 Mei 2003.

Newspaper dan Journal

Paul Suparno, "Pendidikan Multikultural”, Kompas, 7 Januari 2003.

Pranowo, “IPDN Bukan Pusat Pelatihan Binatang”, dalam Kedaulatan Rakyat, Rabu Pon, 11 April 2007.

Robert Cribb (ed.), "The Indonesian Killing of 1965-1966: Studies from Java and Bali”, Monash Papers on Southeast Asia No. 21, 1990.

Samson Prabhakar, "Towards an Education for Peace with Justice: Problems and Prospects", Bangalore Theological Forum. India: United Theological College, Vol. XXV No. 4 \& Vol. XXV No. 1, Dec. 1993 \& 7 March 1994.

Surochman, "Renungan untuk Dunia Pendidikan", Republika, 11 April 2007.

Suseno, Frans Magnis (ed.). 2000. Melawan Kekerasan Tanpa Kekerasan. Yogyakarta: Pustaka Pelajar. 
Tuhuleley, Said (ed.). 2003. Reformasi Pendidikan Muhammadiyah: Suatu Keniscayaan. Yogyakarta: Pustaka Suara Muhammadiyah.

Zaenuddin, Muhammad. 2004. Membangun Wacana Intelektual: Perspektif Keagamaan, Sosial-Kemasyarakatan dan Politik. Yogyakarta: Pustaka Pelajar. 